\title{
Immediate Phonological Features in Representing Regional Identity: Cases of Northern English Vowels in Contemporary Films
}

\author{
Qu Changliang \\ School of English Studies, Dalian University of Foreign Languages, China
}

Copyright $\bigcirc 2018$ by authors, all rights reserved. Authors agree that this article remains permanently open access under the terms of the Creative Commons Attribution License 4.0 International License

\begin{abstract}
In Roman Jakobson's phonological framework of language, although distinctiveness of the phonological units (phonemes as well as distinctive features) is most widely known for its nature of "mediacy", i.e. they fulfill the role of meaning differentiation as signifiants that do not have any direct signifiés, it is their "immediacy" that highlights the last stage of his six-decade-long study of language sound, showing that certain phonological features, mostly non-distinctive, carry direct rather than indirect information that forms an important part of the communication. Features of any linguistic variety may be investigated socio-historically. While the globalized age offers unprecedentedly more opportunities for the English learners in China to be exposed to the English varieties, it is necessary for the English language teaching to give enough socio-historical interpretation to these varieties and their features, especially when they do appear in contemporary popular media. This essay exemplifies the socio-historical role of certain phonological features by illustrating their presence in some typical English films produced in the recent two decades and aims to help understand the cultural implicature of these features so as to offer a bridge to more efficient communication.
\end{abstract}

Keywords Phonological Features, Immediacy, Varieties of English

\section{Introduction}

The phonological features of regional English varieties come to the English language teaching classrooms in China as the new era of communication makes them much more accessible to learners who are enabled to watch all types of English films with an unprecedented freedom of choice. It is also the first time for English learners in China to be exposed to a wide range of English varieties, from the regional varieties within the British Isles, to the national varieties in the Inner Circle, all the way to what we now call World Englishes and New Englishes.

In the ELT classrooms in China, although the phonological differences between British English and American English have long been introduced, the English varieties within the British Isles have seldom attained noticeable place in the teaching materials. When they do appear in the films sporadically, they are often oversimplified as "informal", "uneducated" or "incorrect" forms and therefore only strengthen the stigmatized nature of these stereotyped phonological features.

In reality, regional and social variations often twist into each other [1]. Thus, these phonological features are not merely structural markers to show class distinctions, but more likely participating factors to achieve regional identity.

\section{Immediate Phonological Features and Their Extralinguistic Implications}

Each English variety has its historical and social background and best serves as a key to the cultural heritage behind it. Local colors represented through what is traditionally called "accents" are essential for the character portrayal in the films. Abandoning the derogative pedagogical labels like "informal", "uneducated" or "incorrect", one may well interpret these features with the Jakobsonian term "immediacy" of the phonological features.

As Jakobson \& Waugh [2] suggested in their distinction of "mediacy" and "immediacy" of phonological units (phonemes or distinctive features), the relationship between sound and meaning does not always imply the passive "mediacy" as presented in Saussurean sense of 
signifiants and signifiés. Instead they construct quite often a more active relationship of "immediacy". Phonological units like phonemes and distinctive features may carry information automatically, without relying on any larger linguistic units whose meanings are obvious. Therefore, they become immediate phonological features that independently reveal the speaker's regional, social and cultural background and participate in the construction of his / her identity.

While dialects in England are well known for its complex phonological diversity, the studies on such phonological features cannot stop at the level of social class distinctions. Actually, phonological variation includes much more implications than about social classes [3]. The purposeful employment of such phonological features helps construct what Downes [4] calls "act of identity". They deserve a closer attention than merely labeled as features of uneducated speech of the lower class as in prescriptive studies.

\section{Cases of Northern English Vowels and Their Sociolinguistic Interpretations}

\subsection{The Northern English Vocalic Features in the Films}

Dated back to the Northumbrian version of Old English, Northern English has been a variety that stands for its own linguistic and cultural heritage and never lost its distinctiveness through the history, although the "attitudes" to it has not always been positive in the recent centuries [5].

Today, seen from the popular films, the most observable phonological features of Northern English often distinctively rest in its vocalic distinctiveness. Compared with the consonantal and suprasegmental differences between the Standard English and Northern English, these vocalic features are much more recognizable and often sound impressive to the learners of English. Among the five pronunciation criteria that Trudgill [6] listed for the dialectologists to describe regional differences within England, two are dealing with the vocalic issues:

Criterion 3: BUT as BOOTT, so that they rhyme with PUT, or as BUTT, so that they do not.

\section{Criterion 5: FACE as FAYCE or FEHCE / FAIRCE}

Both of these two features are highly visible in the speech of the characters in the films portraying the life in North England, no matter the topic is the Edwardian romance, the Thatcherian industrial life, or the $21^{\text {st }}$ century urban activities. In the following parts, lines from three films will be cited as examples: The Secret Garden (1993), film adaption of Frances Hodgson Burnett's novel of the same name, a drama fantasy set in early $20^{\text {th }}$ century Yorkshire; Billy Elliot (2000), a drama film set in fictitious northeastern English mining town during the UK miners' strike in the mid-1980s; and Purely Belter (2000), a comedy film about lower-class teenagers in contemporary Newcastle Upon-Tyne.

\subsection{Northern Vocalic Features as Class Markers}

In these films one of the most noticeable phonological features for the audience is the vowel $/ \mathrm{u} /$ in the place of the standard southern $/ \Lambda /$ (no matter it is spelled as $\left\langle\mathrm{u}>,<_{0}>\right.$ or $<\mathrm{ou}>$ ). This feature is traditionally accepted as a hallmark of the Northern speech. Thus it frequently appears in the speech of the characters in the films, especially among the members of the lower class. For example, in The Secret Garden, this $/ \mathrm{u} /$ is highly visible in the servant Martha's speech:

(1) MARTHA: He'd suffered so much already.

$$
/ \mathrm{u} / \quad / \mathrm{u} /
$$

The same vowel also exists in the speech of Billy, a coal miner's son in Billy Elliot and that of Gerry's father, a jobless drunkard in Purely Belter.

(2) BILLY: Are you sure you're not going to come?

$$
/ \mathrm{u} /
$$

(Billy Elliot)

(3) GERRY'S FATHER: She still loves me. She does. I can tell.

$$
/ \mathrm{u} / \quad \begin{gathered}
/ \mathrm{u} / \\
\text { (Purely Belter) }
\end{gathered}
$$

To pronounce the letter $<_{\mathrm{u}}>$ (as well as its variants $<_{0}>$, $<$ ou $>$ etc.) as a higher $/ \mathrm{u} /$ in the stressed closed syllable seems, without exaggeration, a most famous phonological feature of Northern English. Diachronically, this $/ \mathrm{u} /$ is much closer to the original vowel in Middle English and Early Modern English. Its southern counterpart, the lower $/ \mathrm{N} /$, is relatively recent and did not come into being until $17^{\text {th }}$ century. Jespersen [7] speculated that there may have been an unrounded high-back-wide vowel as the transition between them before $/ \mathrm{u} /$ fully lowered to the $/ \mathrm{N} /$ position. But the more conservative $/ u /$ has never completely disappeared, where it is robustly preserved in Northern English pronunciation of words like bus, some, love etc., either as /u/ or as a less round or less back vowel.

Other representative Northern English vocalic phonemes include the long monophthongs / $\varepsilon: /$ and /o:/, also highly visible as indices to the lower class speech. For example,

(4) MARTHA: Mrs. Medlock gave me the place out of kindness to me mother.

$$
\text { /e:/ } \quad / \varepsilon: /
$$

(The Secret Garden)

(5) GERRY: No, cos I'm not goin'.
/o:/
/o:/

(Purely Belter) 
It is necessary for the English learners to know that none of the above-mentioned phonological features are naturally stigmatized. As recorded in the first volume of Jespersen's Modern English Grammar (1909), there used to be clear distinction between long monophthong /a:/ (spelled as $<\mathrm{a}>$ ) and diphthong /æ:i/ (spelled as $<\mathrm{ai}>$ ) in all varieties of English. This distinction was being coalesced in the South during the $17^{\text {th }}$ and $18^{\text {th }}$ centuries, and was completely lost there in the $19^{\text {th }}$ century. The paralleling phenomenon for the back vowel also occurred to the distinction between the long monophthong /o:/ and the diphthong /ou/.

As this fusion was restricted to the South, whose variety of English serves as the standard, the long monophthongs still heard today in Northern English became stigmatized as a marker of the social classes they represent.

\subsection{Northern Vocalic Features as Age Markers}

There is evidence that indicating the social stratification is not the only role of the Northern vocalic features in these films. Some features also serve as the index to a certain age group.

One of such features occasionally visible in the films is the crescendo diphthong /ia/ in words like late and change. For example:

(7) BOXING COACH: Elliot, you're late. Get changed and get in here.

$$
\text { /ia/ } \begin{gathered}
\text { /ia/ } \\
\text { (Billy Elliot) }
\end{gathered}
$$

In this case the vowel in late and changed is neither the "typical" North long monophthong / $/$ :/ nor the South descendo diphthong /ei/. It is pronounced as a crescendo diphthong /ia/ that used to be another traditional hallmark of the Northern English phonology, although it is no longer very prevalent. Consequently, it appears much less frequently in these films. Ihalainen [8] noted that it is still preserved among a considerable number of the older generation, while the majority of Northern English speaker now prefer the long monophthong /ع:/. Thus in Billy Elliot, this feature appears in the speech of the elder rather than the children; in a film portraying the $21^{\text {st }}$ century urban life like Purely Belter, this feature is completely absent. It therefore becomes a marker of an age group instead of a mere marker social stratification.

Again it is worth mentioning that such a feature is not naturally stigmatized. As Wales [9] indicates, the vocalic system of Northern English also experiences its own shifts, some of which can be dated to the era before the Great Vowel Shift. This diphthong/ia/ derived from OE /a:/ on an alternative way from its Southern counterpart.

\subsection{Northern Vocalic Features in the Construction of Regional Identity}

Although Northern English phonological features are quite often associated with the lower class, an appropriate sociolinguistic interpretation should go beyond such stereotyped simplification. In the era of multiculturalism, it is more reasonable to believe that with such phonological features the screen writers and film directors would rather depict the local cultural identity than create any old-fashioned funny, stigmatized characters.

In Purely Belter, Northern English phonological features are employed as part of the cultural atmosphere of Newcastle-upon-Tyne, the most populous northeastern city. These phonological elements well match the city landmarks, the urban activities, as well as the local football fervors depicted in the film.

Its protagonist Gerry undoubtedly belongs to the rough "lower class". He is depicted as a rebellious teenager in a broken family who has dropped out of school and commits various juvenile delinquencies. But it is still inadequate to regard his "Geordie accent" solely as a marker of the social class, for a closer look reveals that the phonological features in his speech can also be found in the speech of the characters of other classes. A typical scene is an argument between Gerry and Maureen, the social worker who tries to persuade him to get back to school:

(8) MAUREEN: So you don't want to know what I've got.

GERRY: No, cos I'm not goin'.

$$
\text { lo:l lo:/ }
$$

$$
\text { /o:/ }
$$

(9) MAUREEN: In fact, I bet you're there today,

$$
\text { le:/ }
$$

dressed up like a prick...

$/ \mathrm{u} /$

GERRY: I don't care what you've got, Maureen.

$$
\text { /o:/ }
$$

I'm not goin'.

$$
\text { /o:/ }
$$

Watch me mouth - I am not goin' to school.

$$
\text { /o:/ }
$$

Not today, nor on any other day.

$$
\text { le:/ le:/ }
$$

Evidently, North vowels like /o:/, /u/, and /e:/ in these cases are not limited to the characters of the lower social class. The Northern phonological features that Maureen employed are not merely strategies of solidarity. With these Geordie elements, the "Newcastle way of life" is convincingly depicted, promoting them as markers of regional identity.

Similar situation is found in Billy Elliot. Set in a background of the 1984-85 coal miners' strike in a fictitious Durham town, the film neatly portrays the industrial legacy of North England. Historically, the $18^{\text {th }}$ 
century Industrial Revolution had pushed North England into the foreground, where coal mines, steelworks, and all sorts of factories and workers soon became cultural symbols of this part of the country.

Billy, the titular character of the film, proves a highly talented boy from a typical working-class family. But again, the way he speaks is not restricted to the working class that he belongs to. While the audience are moved by the kindness and efforts of the ballet teacher Mrs. Wilkinson, they may also notice that her speech is also strewn with Northern English phonological features. For example, in her explanation of The Swan Lake to Billy, one easily finds the North $/ \mathrm{u} /$ in all the places of standard $/ \Lambda /$ :

(10) And this woman, this beautiful woman, is forced to be a swan, except for a few hours every night, when she becomes alive.

/u/

She becomes real again. /u/

And then one night, she meets this young prince, $/ \mathrm{u} /$

and he falls in love with her... /u/

At the first glance, the ballet teacher may have been misunderstood by the audience as a working-class woman due to her rough behavior and speech. But as the story continues, it will be easy for the audience to find that she lives in a comfortable house in the clean residential area of the middle class. Billy is not unconscious of this class difference either, as he did make an effort to dress himself elegantly when he visits her house. In addition, it is interesting to see that Mrs. Wilkinson's husband, who acts like an intellectual quite sensitive to politics, is also portrayed as speaking Northern English instead of Standard English, even if the latter sounds more suitable to his social status. On the contrary, regardless of his social class, he, as an elder, is the only noticeable speaker in the film who pronounces "coal" as /kuəl/, a conservative phonological feature in Northern English that used to be prevalent, but becomes more and more obsolete. Therefore, in spite of their stereotyped role of class indication, these phonological features are employed in this film to reconstruct panoramically the cultural identity of a Durham mining town in the 1980 s.

The only one among the three mentioned films that uses Northern English phonological features as a distinctive class marker is The Secret Garden. Among the main characters, one easily recognizes two groups, each speaking with its own phonological distinctiveness. The Northern English group is represented by the servant Martha and her rigorous brother Dickon, while the Standard English group is represent by the young lord Colin, the "princess-like" Mary and the snobbish head housekeeper Mrs. Medlock.

It is not surprising to see this correspondence between class difference and speech difference, since this film is an adaptation from a classic novel of the Edwardian age. But even in this film, the phonological features of Northern English are not intended to depict the "roughness" of the lower class. Instead they are successful means to characterize their benevolence, for example, like the warm-heartedness of Martha, and the smartness of Dickon. Without their help, the rite-de-passage of Mary would have been impossible to accomplish. In this sense, the Northern English phonological features in the film have well suited the historical heritage, the natural beauty and the unpretentious people of Yorkshire.

\section{Conclusions}

To conclude, although Jakobson is more famous as the initiator of the theory of distinctive features [10] [11], his less known theories like that of immediate phonological features is also beneficial to language teaching and learning. Immediate phonological features in the dialects often reflect the historical development of the language and are not naturally stigmatized forms. Thus it is inappropriate in the English teaching classroom to merely brand them as uneducated or incorrect forms employed by the lower classes. Nowadays, these phonological features are often utilized deliberately to establish the local color and pride through popular media, where they usually facilitate the construction of the regional identity for both the characters and the place. Like all the "local flavors" prevailing in modern tourism, the phonological variants chosen by a character in any film, although often artificially decided by the producer, director, writer/screen writer(s), actor/actress, and/or production manager, are undoubtedly efforts made for an augmentation of authenticity and for the promotion of the film itself. Therefore decoding these factors are constructive for English language teaching and learning. When teachers and learners are investigating the socio-historical sources of the frequently seen phonological features of the English varieties, the information that they carry naturally surfaces and their cultural role is often discovered much more profound than the audience have usually expected.

\section{Acknowledgements}

This work is part of the Project "Theory of Phonological Evolution and Its Applications in English Vocabulary Teaching" supported by the 13th 5-Year Plan of Educational Science of Liaoning Province (No. JG17DB104). 


\section{REFERENCES}

[1] J. Rickford. Regional and social variation, Sociolinguistics and Language Teaching, Shanghai Foreign Language Education Press, Shanghai, 151-194, 2001.

[2] R. Jakobson, L. Waugh. The Sound Shape of Language, Indiana University Press, Bloomington, 1979.

[3] P. Foulkes, G. Docherty. Phonological variation in England, Language in the British Isles, Cambridge University Press, Cambridge, 52-74, 2007.

[4] W. Downes. Language and Society, Foreign Language Teaching and Research Press, Beijing, 2011.

[5] J. Holmes. An Introduction to Sociolinguistics, World Publishing Corporation, Beijing, 2011.
[6] P. Trudgill. Dialects, Routledge, London, 1994.

[7] O. Jespersen. A Modern Grammar of the English Language on Historical Principle, Vol. 1, Sound and Spelling, George Allen \& Unwin Ltd., London, 1909.

[8] O. Ihalainen. The dialects of England since 1776, The Cambridge History of the English Language, Vol. 5, Peking University Press, Beijing, 197-263.

[9] K. Wales. Northern English: A Cultural and Social History, Cambridge University Press, Cambridge, 2006.

[10] R. Jakobson, G. Fant, M. Halle, Preliminaries to Speech Analysis. MIT Press, Cambridge, 1952.

[11] R. Jakobson, M. Halle. Fundamentals of Language, Mouton, The Hague, 1956. 